\title{
Development of Economic Forest Plantation Management in Thailand
}

\author{
Wisuthra Intongkaew ${ }^{1}$, Liu Junchang²
}

\author{
${ }^{1}$ School of Economics and Management, Beijing Forestry University, No 35, Qinghua East Road, Haidian \\ District, Beijing, Peoples Republic of China, Post Code -100083 \\ ${ }^{2} \mathrm{Ph}$. D, Professor, School of Forest Economics and Management, Beijing Forestry University, Beijing, P.R. China
}

\begin{abstract}
Economic Forest as a forest plantation in private land is the target area of the government forest policy to increase forest area. Such target not only increase forest area, but also timber consumption within the country and export. Consequently, the Royal Thai Government (RTG) by Royal Forest Department (RFD) have to encourage the private companies, individual farmers and other sectors participate in increasing economic forest plantation area. At the same time, the government sector, needs to develop the economic forest plantation management, namely; improve the law due to the problem of verifying the timber source as forest plantation or natural forest for confident of the rights and benefits of the forest plantation, support of economic forest plantation is still in operate concurrently with improve the process of regulations and technology for service to facilitate the several stakeholders according to levels of production, and the RFD have projects to promote an individual farmer to plant forest plantation by supporting subsidy and conditioned planting long rotation trees and planting short rotation trees which are worthwhile investment and give high benefit. Nevertheless, in terms of the government management had taken the growing timber demand into account by combining with sustainable management of natural forests and development of efficient production from forest plantations in order to increase forest area according to the National Forest Policy.
\end{abstract}

Keywords: National Forest Policy, Economic Forest Plantation Management, Support and Promotion

\section{INTRODUCTION}

In Thailand the reforestation in the private land is the economic forest plantation, that one of target to increase the forest area, has also been carried out by private sectors for more than 30 years. Teak (Tectona grandis), Pinus spp., Casuarina spp., Eucalyptus spp. And Acacia spp. are the main tree species selected for reforestation. Due to depletion of forest resources and logging ban lead to a decline in domestic supply so necessary to import from neighboring countries. In terms of the government sector will have to incentive enhance wood supply from forest plantations and increase the economic forest plantations at the same time. Therefore, Royal Thai Government RTG by Royal Forest Department (RFD) need to develop the economic forest plantation management in order to encourage the private sector to participate in the planting economic forest plantation.

Current Situation Natural resources and the environment in Thailand have been affected by worldwide events including both climate change and domestic factors such as population increase. Growth-oriented development and competition in trade and investment have materially contributed to the exploitation of natural resources beyond the carrying capacity of the ecosystem. At the same time, management capability and policy tool such as databases, regulations, law enforcement, and economic instruments have not been utilized efficiently. This has led to depletion of natural resources and deterioration of the environment, thereby, has affected the overall balance of the ecosystem (NESDB, 2016).

In Thailand, the national forest policy has the important instrument in order to focus on the forest resources management in Thailand. According to the National Economic and Social Development Board, target of natural capital and environmental quality is to be able to support green growth. The proportion of land under forest cover should be $40 \%$ of the country area in order to underpin a balanced ecology system. An indicator of this target is forty percent of the country area must have covered by forest which is divided into forest for conservation and commercial forest in the proportion of 25 and 15 percent of the country are, respectively (NESDB, 2017).

According to the National Forest Policy and the Twelfth National Economic and Social Development 
Plan $\left(12^{\text {th }}\right.$ plan $)$, forest cover is targeted at $40 \%$ of the country area, but its current cover $31.58 \%$, excluding fruit tree orchards and rubber plantation (RFD, 2017a). The government main tasks in the conservation forest area are to protect remaining forests, and restore degraded forests namely,

I Conservation forests with the targeted area of $25 \%$ of the country area.

$>$ Areas; Conserved forest areas and national reserved forest areas.

$>$ Activities have been divided into 2 parts; the first is a conserved forest area with intensive management, composing of national parks, forest parks, wildlife sanctuaries, nonhunting areas, botanical gardens and arboreta. The second one is a national reserve forest area which can be allocated for optimal utilization. This area is managed by smart patrol, law enforcement, forest land management, community forestry promotion, forest rehabilitation in degraded areas and forest restoration

II. Commercial forests with the targeted area of $15 \%$ of the country area.

$>$ Area; private lands.

$>$ Activities; consist of support private area, state enterprise plantation, promotion of afforestation in private land for forest plantation (commercial).

Currently, the RTG has proposed a policy to resolve the degraded forest resources that are still threatened and destroyed by human and natural disasters. It is a long-term effect of the government in allocating areas for livelihood in the degraded forests. Due to the indeterminate territory map, conservation areas are still invaded and deforested continuously. Forest destruction has occurred due to the demand of forest land by rural people for residential and agriculture as well as the occupation of large forest areas by the capitalists for construction of resorts or large-scale agriculture, such as rubber plantations, oil palm plantations. To diminish deforestation and recover forest over, the government has formulated a number of projects to promote planting economic forests for use in household and support the private sector.

The RTG has different policies and regulations for management in different areas. The conservation areas and national reserved forest areas are managed directly by government agencies, while the implementation in private lands is only supported and promoted by government agencies through regulations and policies only.

\section{ECONOMIC FOREST PLANTATION IN THAILAND}

\subsection{Concept of forest plantation.}

According to the objectives of afforestation, type of forest plantation includes:

I. Protection plantation (national forest), rehabilitation of disturbed watershed areas and re-afforestation of disturbed forests;

II. Amenity plantation (national forest), Some areas have been reforested for amenity or aesthetic purposes but not for timber production; and

III. Production plantation (private land), Forest plantations for production plantation (private land) aim to encourage the private sector and local farmers to grow commercial trees in order to supply the domestic market and reduce imports. The RFD has carried out campaign very hard to encourage the private sector to invest in forest plantations.

The concept is to plan forests in order to change the agricultural areas or bare land by planting forests for the economic benefit. Forest plantation must be priced at a higher value and more land must be utilized. For forest plantation, selected tree species are brought to plant in the areas under the exact procedure and purpose for economic returns directly or indirectly. Selection of type of plant for growing, areas and technique depending on the objective that important. To make the investment beneficial and well worth, the forest plantation, which be small, medium or large business, is needed to be maintained as well, otherwise, it will be a wasted investment. The success of planting forests not only depends on tree species selection suitable to the areas, selection of quality seedlings, planting procedure and maintenance. These factors are equivalent importance.

According to Forest Plantation Act B.E. 2535 (1992), and subsequent amendments B.E. 2558 (2015), the word 'forest plantation' means land registered to do the planting and maintenance of trees on lands that are attached by a title deed or certificate of benefits under the Land Law, or on the lands in the land reform area under the Agricultural Land Reform Act, with proof of license, rent, lease, transfer or inheritance.

\subsection{Forest Plantation situation}

In the past, timber was an important export commodity and played a significant role in Thailand's economic development. Foreign timber companies had harvested teak from natural stands in the north from the end of the nineteenth century. The history of restoration by forest plantation in Thailand began in 1906. The RFD established a forest plantation of teak was in a shifting-cultivated area at 
Mae Pan Forest, Sungmen District in Phrae Province in the north of Thailand, by Phraya Wanphrukphijarn (Thongkham Savetsila), who further continued to establish a few planting trials in subsequent years.

In 1941, the reforestation program became the mandate of the RFD and, thereafter, plantations have been established for both teak and other timber species annually according to the allocated budget (RFD, 2009).

In 1968, the RFD started to place all forest lands under management plans and prepared timberharvesting schemes. This was necessary as the poor condition of many over-logged forests indicated over exploitation; forest stands had deteriorated faster and yields from the second cut were quite low. Forest management plans have been reviewed and improved several times to suit environmental conditions and economic situations.

To protect the forest from over exploitation, in 1979 half of the forests that previously had been made available for exploitation were closed to timber harvesting and it was hoped that these forests would recover naturally to their abundant original condition. However, existing logging roads provided access for poor and landless people to convert forests into farmlands.

The forest plantations established by RFD consist of commercial plantations, watershed improvement plantations, plantations for restoration of degraded national forests, plantations for environmental conservation and plantations for the Royal Initiative Projects.The organizations that dealing with reforestation of country are Royal Forest Department(RFD),Department of National Parks, Wildlife and Plant Conservation (DNP), Department of Marine and Coastal Resources(DMCR) and two state enterprises, namely Forest Industry Organization (FIO) and Thai Plywood Co.,Ltd (RFD, 2009).

The 2 government organizations responsible in commercial plantations are FID and RFD. The Forest Industry Organization (FIO), a state enterprise, started a forest plantation program in 1967 with teak as the main species. The timber is not old enough to be harvested yet. The organization has been affected by the logging ban since 1989 . Due to the need to reduce the timber imports from neighboring countries, the Royal Forest Department (RFD); the responsible agency for implementing various activities in protected forest, restoration, rehabilitation, including promotion of reforestation in private land, launched a forest plantation promotion project in 1994 to encourage and support private land owners and local farmers in order to establish forest plantations of commercial tree (APFNet,2016). The total plantation areas established by government organizations by 2007 amounted to $1,302,647$ hectares (RFD, 2007).

Event though, this project is useful, the amount of forest plantations established under this program is still below the target. To achieve the target, some commercial companies and semi-private enterprises were supported by the RFD in establishing forest plantations. Furthermore, the RFD created another way to increase the forest plantation by supporting free tree seedlings to local communities, farmers and institutions. Comparing to the target of the government, however, the consequence empirical number of forest plantation is still below.

Royal Forest Department has implemented a restoration program and established plantations of teak and other timber species annually according to allocated budget. The private sector has actively been involved in restoration efforts for over 30 years. Many kinds of tree such as Teak, Pines, Casuarina, Acacia and Eucalyptus are the main tree species for restoration by private sectors. Particularly, Eucalyptus camaldulensis, which is an exotic fast-growing tree species, is the mostly chosen for restoration by private sectors and is widely preferred by private investors due to its rapid growth.

Reduction of forest resources and logging ban have led to decline in domestic timber supply and resulted to the requirement of wood import from neighboring countries. According to the Table 1, the trend of round wood demands as raw materials in Thailand from 2016 to 2036 is getting higher and higher. To satisfy such demand of round wood as raw material for consumption in the long run, Thai government have, therefore, developed policies to enhance wood supply from forest plantations for the industries groups, particularly, for the commercial industry that consumes round wood as raw material higher than other groups at all times. Consequently, the management with the appropriate alternatives is important to implement for increasing the economic forest plantation together with the conservation by taking into account utilization for sustainable management. 
Table 1; Current (2016) demand and forecast of round wood as raw materials in Thailand.

\begin{tabular}{|c|c|c|c|c|c|}
\hline \multirow[t]{2}{*}{$\begin{array}{c}\text { INDUSTRY GROUPS } \\
\text { AND THE USE OF WOOD }\end{array}$} & \multicolumn{5}{|c|}{$\begin{array}{l}\text { WOOD CONSUMPTION } \\
\text { (Unit: million tons) }\end{array}$} \\
\hline & 2005 & $2016^{1 /+3 /}$ & $2021^{2 /+3 /}$ & $2026^{2 /+3 /}$ & $2036^{2 /+3 /}$ \\
\hline 1. Pulps (Paper\& Dissolving) & & 7 & 7 & 9 & 10 \\
\hline 2.Wood Chips (for Export) & & 6 & 10 & 15 & 20 \\
\hline 3.Wood Composites (PW, PB, FB, CBB, WPC) & & 6 & 10 & 18 & 32 \\
\hline 4.Sawn lumber (for furniture \& Construction) & & 7 & 8 & 9 & 11 \\
\hline 5.Mushroom/Fertilizer & & 0.5 & 0.75 & 1 & 2 \\
\hline 6.Pole/Pile/Scaffold & & 0.5 & 0.75 & 1 & 2 \\
\hline 7.Household Energy (fuel wood, charcoal) & & 15 & 15 & 15 & 15 \\
\hline 8.* Commercial Energy (Chips, pellet, charcoal) & & 16 & 28 & 32 & 64 \\
\hline Total & 40 & 58 & 79.5 & 100 & 156 \\
\hline
\end{tabular}

Note: $\mathrm{PW}=$ Plywood, $\mathrm{PB}=$ Particle Board, FB = Fiber Board, $\mathrm{CBB}=$ Cement Bonded Board, WP $=$ Wood Plastic Composite.

* Assess from the electricity generation plan from biomass $(5570-2300 * 20,000)$ and Wood pellet for export approximately 5 million tons/year (2019) Excludes the use as fuel for thermal energy

Source: 1/ Fast Growing Tree Association, 2/Thai - Forest Certification Network, 3/ Faculty of

Forestry, Kasetsart University.

\section{ECONOMIC FOREST PLANTATION MANAGEMENT}

Nowadays, The RFD has tried to increase the forest plantation in private areas to meet the National Forest Policy and the policy of the Ministry of Natural Resources and Environment (MoNRE) (Jongklai,2017) by:

I. Development of forest industry, and

II. Promotion of planting of valuable trees in ownership lands, and can be cut for sale, and encourage the private sector to invest in forest plantations.

Specific strategic issue of the Royal Forest Department in period of 20 years, $2017-2036$, related to the forest economy is Strategic Issue 3: Promotion of Forest Business and Economic Forests in forest planting and community promotion in order to make urban / rural communities to be green areas with 2 purpose:1) to increase green forest and economic forest outside the forest area, and 2) to increase green area in urban / rural communities, and 2 indicators: 1) There is 8.68 million Rai of green forest and the economic forest area outside the forest areas, and 2) 3,860.8 million green seedlings are distributed to increase the green areas (RFD, 2017b) This consists of 6 strategies;

Strategy 1. Promote and support the afforestation in economic forests as follows;

$>$ Survey and prepare economic forest planting database.

$>$ Encourage people to plant a forest in their own lands, for forest management, legal regulation, tax deduction, wood purchasing, including innovation.
$>$ Provide and support funding both shortterm and long-term financial sources to various types of economic forests.

$>$ Provide a number of quality seedlings to growers corresponding to the needs and mechanisms of the market.

$>$ Encourage and support industries that use wood as a raw material for domestic production and export.

$>$ Transfer technical knowledge to forest economic growers in order to increase productivity and income

Strategy 2. Promote and support the integration and establishment of forest growers as follows;

$>$ Promote and support the integration and the establishment of a strong forest grower network.

$>$ Survey and develop a database of growers.

$>$ Link forest growers and timber purchase sources for the benefit of forest management services, marketing promotion.

Strategy 3. Promote and support the planting of valuable trees as follows;

$>$ Study and analyses valuable timber species, including knowledge of planting, maintenance, utilization and marketing.

$>$ Encourage to plant valuable trees in order to increase the volume of timber in the country.

$>$ Support to plant valuable trees under the theory of sufficiency economy or Agroforestry. 
$>$ Develop techniques to utilize valuable timber.

Strategy 4. Increase and develop green areas in urban and community areas. as follows;

$>$ Explore and develop an existing green space database and potential areas for urban and community development.

$>$ Target green areas in urban and community areas.

$>$ Seek cooperation and support from both public and private agencies to increase and develop green spaces in urban and community areas.

$>$ Strengthen the local government organization to promote and support the planting of trees outside the forest.

Strategy 5. Promote and support participation in increasing green area as follows;

Distribute quality seedling nurseries to the public, private sector, government agencies and interested parties in order to promote participation in planting trees for green areas.

$>$ Increase efficiency and productivity of seedlings.

$>$ Monitor and evaluate the distribution of seedlings and tree planting according to statistics as well as prepare database and modern technology.

$>$ Developing nursery techniques.

$>$ Development of personnel in seedling nursery, including promotion and dissemination.

$>$ Encourage and support the commercialization of valuable and economically valuable timber to promote economic, community and conservation.

$>$ Promote tree planting to prevent saline spread in the Northeast.

Strategy 6. Develop a standard forest certification system Forest Certification as follows;

$>$ Develop appropriate National \& Indicators for sustainable forest resource management by integrating with relevant stakeholders.

$>$ Transfer knowledge and prepare all sectors to implement international forest certification standards.

According to the policies related to the forest strategies above, the RFD has developed methods of the management for private companies, individual farmers and others sectors, according to responsibility, research on and training on the mass production of superior tree seedlings, utilizing biotechnology are essential in order to successful. Moreover, enhance in technology and implementation of sustainable forest management needed to be prepared for negotiations with the European Union, ASEAN and other international organization standards. Thailand's timber tracking system is created to use electronic equipment in order to manage the database and network information exchange for National Single Window. Sustainable forest Management which is significant for forest plantation management aims to maintain and enhance the economic, social and environmental value of all types of forests, for the benefit of present and future generations by collaboration. Hence, not only promoting the private sector to plant the forest but also promotion of the marketing is required to take into account the international export standards in order to enable farmers to manage in line with the steps of the international export, standards.

\subsection{Management underneath the law}

The laws related to the implementation of forest plantation by each sector are as follow;

$>$ Forest Act B.E. 2484 (1941) and subsequent amendment B.E. 2532 (1989), in terms of definition of royal tree and control the forest industries,

$>\quad$ National Reserved Forest Act B.E. 2507 (1964) and subsequent amendment B.E. 2522 (1979 and B.E. 2528 (1985), B.E.2559(2015), in terms of authorization for National Forests,

$>$ Forest Plantation Act B.E. 2535(1992), and subsequent amendment B.E. 2558 (2015),

$>$ Chain saw Act B.E. 2545 (2002) on control, possession and use of chainsaws that does not affect deforestation.

All the forest laws are concerning forest plantation. Most of them have the main objectives to manage the forest plantation, However, the Forest Plantation Act B.E. 2535 (1992), and subsequent amendment B.E. 2558 (2015), are the most important laws for forest plantation.

Forest Plantation Act B.E. 2535 (1992) and subsequent amendment B.E. 2558 (2015), the government has a policy to promote more extensive commercial and private plantations for public and private land. But because the Forest Act B.E. 2484 (1941) and subsequent amendment B.E. 2532 (1989), at that time, there is no provision to support and protect the right to forest protection from the forest. Hence, there is a law on forest plantations to support and promote the plantation. In order to encourage people to work and produce wood to be productive as well as increase the amount of forest area and for those who are going to build a forest plantation, they are confident of the rights and benefits of the forest plantation for example, being exempt from royalties 
and not subject to certain rules as defined in the Forest Act of 1941, it is necessary to enact this law.

Development through the electronic system,

$>$ Add channel for submission.

$>$ Facilitate the private sector that interested in planting trees; to receive the certificate, to use the barcode and QR code helps to verify the information and notification to the relevant information.

$>$ The private sector and the relevant authorities can monitor each step of the operation at any time, and can solve problems quickly.

$>$ Have a current database, to benefit the public and private sectors in planning, management and marketing.

$>$ The system helps promoting economic forest plantation to be transparency in accordance with the prescribed legal regulations of the applicable law.

\subsection{Supporting the economic forest plantation}

In its efforts to strengthen sustainable forest management, Forest Plantation Act B.E. 2535 (1992), and subsequent amendment B.E. 2558 (2015) provide incentives to forest plantation owners by way of permitting free moving of timber produced from the plantations. Without the act, the transportation of any $\operatorname{logs}$, even planted and cut from private land, was controlled strictly by the regulation, being considered as disincentive in investing in commercial plantations. There are a number of private companies and individual farmers who invest in forest plantation, mostly teak and eucalyptus and many have formed Forest Farm Cooperatives to strengthen their efforts. These cooperatives receive some limited support from the government, mainly in the form of planting materials and technical advice on plantation management in addition to capacity building in marketing. That is the one of the government regulations required to be revised in order to raise confidence for the farmer.

The operation supports private companies, Forest Farm Cooperatives, semi-private enterprises and individual farmers in order to facilitate them from the farm to the market. The RFD, in collaboration with other relevant organizations, has also made an effort to develop each step as follow:

$>$ Improve inconvenience laws and reduce some of the authorization process under the Licensing Facilitation Act, B.E. 2558 (2015). Each government agency shall, in rendering licensing facilitation to the public, establish its Service Link Center to accept all applications for licenses, and to provide license-related information as prescribed by the laws related to licensing under its responsibilities to the public in accordance with the guideline laid down by the PublicSector Development Commission (Niwat,2017).

$>$ Using the e-Tree system ${ }^{1}$, certifying timbers on ownership lands with the prescribed legal regulations of the applicable law (Thada,2017).

$>$ Cooperate with stakeholders ${ }^{2}$ in developing the operation in each step to point out the demand of the forestry industry (Seri,2017).

$>$ Develop the National Single Window system; NSW, ${ }^{3}$ for the forest sector, i.e. RFD Single Window System for use in electronic transactions, such as in order to request for a timber moving license, a certified document, a wood certification and an export license, including wood verification, and for a certificate of fact import chainsaws for convenience, reduce the use of paper and check the status of the operation at all stages (RFD, Forest Certification Office,2017). The illustration of the Linking system RFD Single Window is shown in Figure 1.

$>$ Negotiate the framework of cooperation with Forest Law Enforcement, Governance and Trade; FLEGT, which is a measure of the European Union's initiative to tackle the problem of illegal logging and deprivation of timber trade including wood products from illegal timber. In complying with the

\footnotetext{
${ }^{1}$ Storage system for planting trees to create a source of wood and store the stock of wood.

${ }^{2} \mathrm{~A}$ stakeholder is any individual, social group or institution that is affected by or has influence on forestry. Stakeholders may or may not be formally organized, source: FAO (2010).

${ }^{3}$ NSW system of Thailand develop based on the concept of United Nation, the World Customs Organization and the ASEAN Agreement for the Establishment of an ASEAN Single Window under the ASEAN Economic Community (AEC) by 2015 , with the scope of development of the NSW system. For import Exporting and Logistics is the development of knowledge and understanding for both government and business sectors. Including the development of cooperation with international organizations such as economic cooperation in APEC, ASEAN, World Customs Organization (WCO) and United Nations (UN). The Customs Department, Ministry of Finance is the hosts establishment of the National Single Window of the country in accordance with the ASEAN Agreement for the Establishment of the ASEAN Single Window. ( Vichan. 2016)
} 
EU FLEGT Action Plan ${ }^{4}$, seven measures are set out in order to prevent the importation of illegal timber into the EU, improve the supply of legal timber and increase demand for timber from responsibly managed forests. Under the FLEGT Action Plan, in 2005, the EU adopted the FLEGT Regulation. The FLEGT Regulation empowers the European Commission to negotiate bilateral trade deals called Voluntary Partnership Agreements; VPA ${ }^{5}$, with timber-exporting countries.

The FLEGT operation in Thailand; On September 16, 2010, the Forest Department was responsible for coordinating FLEGT operation. The Ministry of Natural Resources and the Environment has issued an order No. 187/2011, dated June 7, 2011, establishing the National FLEGT Board, chaired by the Permanent of the Ministry of Natural Resources and Environment and a Thai negotiating team. Later in 2013, the RFD established Thai-EU FLEGT Secretariat Office; TEFSO. The agency, which is under responsibility of the Director General of the RFD, has a duty to coordinate and carry out various aspects of FLEGT in Thailand, while the Forest Certification Office in the RFD is working to ensure that the certification process meets the standards and the FLEGT.Such operation follows not only EU FLEGT but also still working following other standard such as Forest Stewardship Council, FSC ${ }^{6}$ and Program for the Endorsement of Forest $\mathrm{C}$ e $\mathrm{r}$ t i f i c a t i o n, P E F C?

4 1. Supporting timber-producing countries 2. Promoting trade in legal timber 3. Promoting environmentally and socially beneficial public procurement policies 4. Supporting private-sector initiatives 5. Financing and investment safeguards 6 . Using existing or new legislation 7. Addressing the problem of conflict timber.

5 A bilateral timber-trade agreement between the European Union and a timber-exporting country outside the EU. VPAs are a key element of the EU FLEGT Action Plan, which aims to address illegal logging.

${ }^{6}$ The Forest Stewardship Council is an international nonprofit, multi-stakeholder organization established in 1993 to promote responsible management of the world's forests. The FSC does this by setting standards on forest products, along with certifying and labelling them as eco-friendly.

7 an international, non-profit, non-governmental organization which promotes sustainable forest management through independent third-party certification.

It is considered the certification system of choice for small forest owners. 
Figure 1: The illustration of the Linking system RFD Single Window

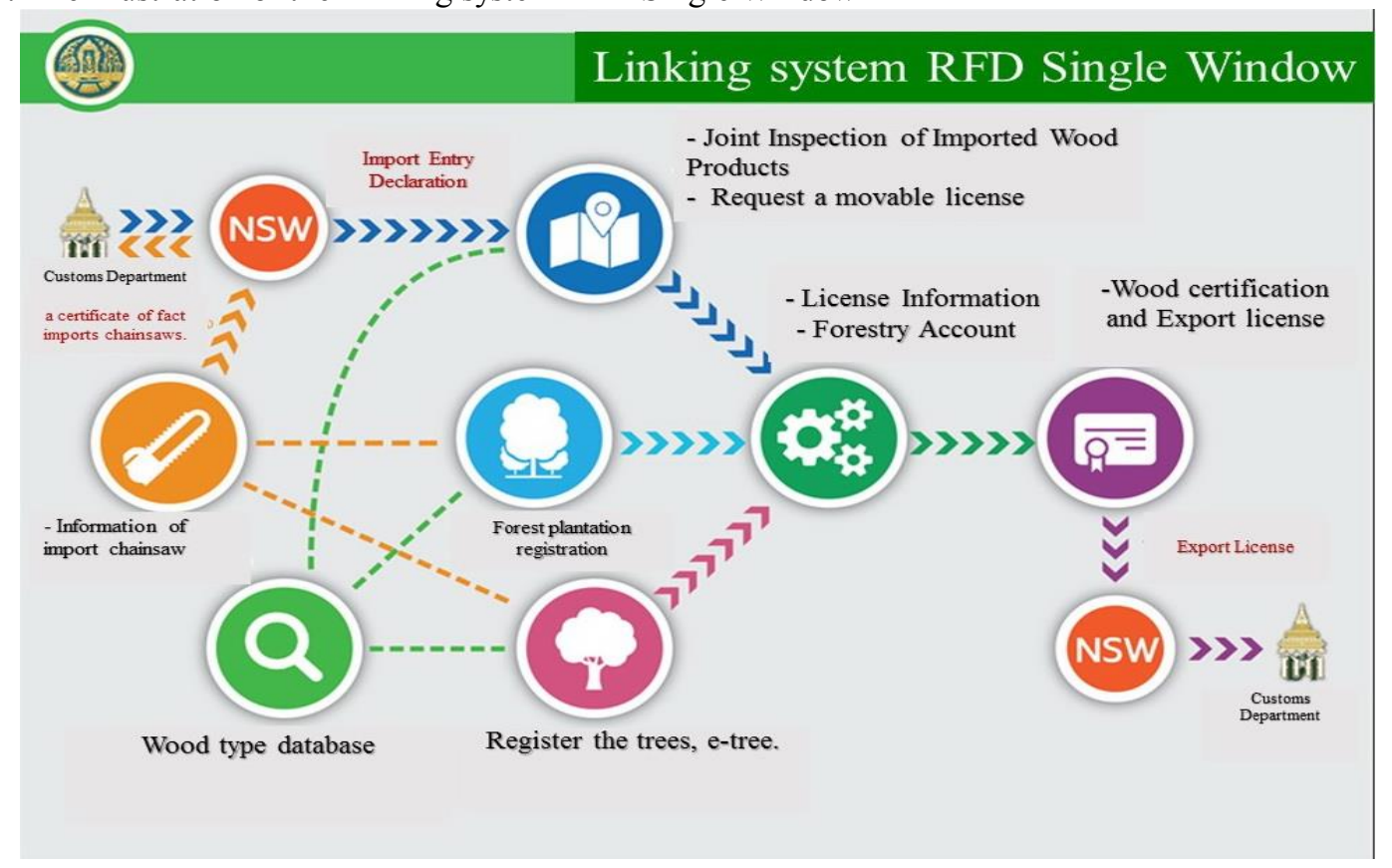

Source: Royal Forest Department, Forest Certification Office.

\subsection{Promoting economic forest plantation.}

RFD as a working unit of the government sector, must perform on this mission and create methods to increase a number of forest plantation areas according to the policies such as distribute seedling, promote plantation in the other area. Nowadays the RFD by Private Reforestation Division, Forest Plantation Extension Bureau has the target to promote planting trees for the wood industries enough to meet the domestic demand on wood in quantity of 47.40 million tons per year and planting area of 20.04 Million $\mathrm{Rai}^{8}$ as shown in the Table 2. Hence the RFD determines 3 targets to promote individual farmer or other sectors to plant trees namely;

order to:

\section{Promote planting fast growing trees in}

Planting fast growing tree for industry and

$>$ Planting fast growing tree for renewable energy.

II. Promote planting long rotation trees.

III. Promote inter-planting economic trees in the rubber plantation and agricultural area.

According to Table 2, demand of Thai wood industry for the type of wood as fast-growing tree is higher proportion compare to the type of wood as long

\footnotetext{
${ }^{8}$ Rai is unit of area 1 Rai equal to 1,600 square meters, 6.25 Rai equal to 1 ha.
}

rotation trees. Taking into account the value of the investment, higher demand is not only better, but also necessary. Hence, the RFD must promote alternative and optimal projects for the individual farmer and private companies economic forest plantation (Nikom,2017). 
Table 2: Wood demand, divide by Wood Industry

\begin{tabular}{llccl}
\hline No & Types of Thai Wood Industry & $\begin{array}{c}\text { Wood demand } \\
\text { Million tons/year) }\end{array}$ & $\begin{array}{c}\text { Planting Area } \\
\text { (Million Rai) }\end{array}$ & Type of wood \\
\hline 1 & Pulp Industry (Paper \&Dissolving) & 7.00 & 2.34 & Fast- growing tree \\
\hline 2 & $\begin{array}{l}\text { Wood Composites Industry (PB, } \\
\text { MDF, HDF, HB, CBPB, WPC) }\end{array}$ & 7.00 & 2.34 & $\begin{array}{l}\text { Fast- growing tree (include } \\
\text { rubber wood and fruit tree) }\end{array}$ \\
\hline 3 & Wood Chip Industry & 11.00 & 3.67 & Fast- growing tree \\
\hline 4 & Construction Industry & 6.50 & 0.42 & Long cutting cycle \\
\hline 5 & Furniture industry & 2.40 & 0.11 & $\begin{array}{l}\text { Fast- growing tree, long } \\
\text { rotation trees }\end{array}$ \\
\hline 6 & $\begin{array}{l}\text { Power Industry (Electricity \& } \\
\text { Heat Pellet) }\end{array}$ & 3.00 & 1.00 & $\begin{array}{l}\text { Fast-growing tree (others } \\
\text { and waste from the } \\
\text { production process) }\end{array}$ \\
\hline 7 & Mushroom \& Fertilizer Industry & 0.50 & & Sawdust \\
\hline 8 & Charcoal \& Fuel Wood Industry & 10.00 & 0.17 & Fuelwood \\
\hline & $\quad$ Total & 47.40 & 10.00 & 20.04 \\
\hline
\end{tabular}

Note; $\mathrm{PB}=$ Particleboard, $\mathrm{HB}=$ Hardboard, MDF $=$ Medium Density Fiberboard, $\mathrm{CBPB}=\mathrm{Cement}-$ bonded

Particleboard, HDF = High Density Fiberboard, WPC = Wood Plastic Composite.

Source: RFD by Private Reforestation Division, Forest Plantation Extension Bureau

\subsection{The area for promoting economic forest plantation}

The restoration action plan under the Forest Reform Action Plan targets the economic forest plantation into 2 parts, 1) state area of 4,100,550 Rai and 2) private area of 3,904,930 Rai and amounted to a total of 8,005,840 Rai (Jongklai,2017). According to the National Economic and Social Development Plan, the target of promoting economic tree plantation on private area for 21 years, as shown in the Table 3 , was divided into 5 period of and now is in the $12^{\text {th }}$ plan at the period of 2017-2021. The forest industry consists of 3 types 1) promote planting fast growing trees with a total target area of 1,924,930 Rai is the biggest target area for promotion because the demand of wood is highest result to the highest requirement the area for planting as appeared in Table 3,2) promote planting long rotation trees with a total target area of 1,010,000 Rai is the second largest target area for promotion, and 3 ) promote interplanting planting economic trees in the rubber plantation and agricultural area with a total target area of 970,000 Rai. The third one will be commenced in 2018.

Table 3 Target of promoting economic tree plantation on private area. (According to the Forest Reform Action Plan,2016-2036)

Unit: Rai

\begin{tabular}{lccccccc}
\hline \multicolumn{1}{c}{$\begin{array}{c}\text { Type of forest } \\
\text { industry }\end{array}$} & $\mathbf{2 0 1 6}$ & $\mathbf{2 0 1 7}$ & $\mathbf{2 0 1 8 - 2 0 2 1}$ & $\mathbf{2 0 2 2 - 2 0 2 6}$ & $\mathbf{2 0 2 7 - 2 0 3 1}$ & $\mathbf{2 0 3 2 - 2 0 3 6}$ & Total \\
\cline { 2 - 6 } & 11,330 & 13,600 & 400,000 & 500,000 & 500,000 & 500,000 & $1,924,930$ \\
\hline $\begin{array}{l}\text { Promote planting fast } \\
\text { growing trees. }\end{array}$ & & & & & & & \\
\hline $\begin{array}{l}\text { Promote planting } \\
\text { long ratation trees. }\end{array}$ & 40,000 & 20,000 & 200,000 & 250,000 & 250,000 & 250,000 & $1,010,000$ \\
\hline $\begin{array}{l}\text { Promote inter- } \\
\text { planting economic } \\
\text { trees in the rubber } \\
\text { plantation and } \\
\text { agricultural area. }\end{array}$ & & & & & & & \\
\hline Total & & & & & & & \\
\hline
\end{tabular}

Source: RFD by Private Reforestation Division, Forest Plantation Extension Bureau 


\subsection{The Project for supporting and promoting economic forest plantation.}

In 2016, the RFD developed a "Promotion of Forest

Plantation for Economic, Social and Environmental Project" (Planning and Budgeting Division, RFD, 2016). The project gave an incentive to farmers who were interested in participating in the project by subsidizing a total 5,000 baht as support for 5 years. The money was paid on the instalment basis in an amount of 1,000; 700; 800; 900 and 1,600 Baht/Rai/year in the $1^{\text {st }}, 2^{\text {nd }}, 3^{\text {rd }}, 4^{\text {th }}$ and $5^{\text {th }}$ year, respectively. Moreover, 200 quality seedlings per Rai were also provided for planting. This was a project for planting long rotation trees and appropriate for persons who required high benefits in a long period, by selecting the species suitable to planting areas and the most popular selection was teak due to high-return.

In 2017, the RFD formulated a "Promotion of Planting Fast Growing Tree for Industry Project" (Planning and Budgeting Division, RFD, 2017), The project created an incentive by subsidizing a total 3,000 baht as support for 3 years to farmers who were interested in participating in the project. The money was paid on the instalment basis in an amount of 1,$500 ; 800$ and $700 \mathrm{Baht} / \mathrm{Rai} / \mathrm{year}$ in the $1^{\text {st }}, 2^{\text {nd }}$ and $3^{\text {rd }}$ year, respectively. Furthermore, 300 quality seedlings per Rai were also provided for planting. This project promoted planting of short rotation trees which could harvested in a shorter time and get a return faster.

The "Promotion of Planting Fast Growing Tree for Renewable Energy Project" supported 1,000 quality seedlings for planting per Rai. In addition, groups of farmers in the target areas were established to support entrepreneurs while technical knowledge and management of forest plantations were provided to such groups.

The "Promotion Interplanting Economic Trees on The Rubber Plantation and Agricultural Areas Project", for example, interplanting Magnolia champaca in the rubber plantation, interplanting teak in pineapple fields, interplanting teak in banana farms and so on. supported 50 quality seedlings per Rai for inter-planting in the main planting

The RFD must provide information regarding investment value and return to individual farmer and private companies under the "Promotion of Forest Plantation for Economic, Social and Environmental Project" and the "Promotion of Planting Fast Growing Tree for Industry Project" for comparing between long rotation trees and short rotation trees.

\section{CONCLUSION}

Economic forest plantation management by the government sector must be carried out by supporting the operation of the private companies, Forest Farm Cooperatives, semi-private enterprises, individual farmers and others stakeholders in terms of technique, technology development, law improvement, stakeholder cooperation, negotiation the framework of cooperation and develop all process in order to facilitate in service. Promotion of forest plantation is a method that the RFD have tried to increase forest plantation areas by developing projects with high requirement from the farmer and worthwhile investment based on the weather suitable to tree species. If it is appropriate to harvest, it will be a possibility to get more benefit. The demand of the market is a main factor in selecting tree species for high yield plantation. Thus, promotion to plant the long rotation trees needs to take a long time for harvesting, but gives more benefit, and promoting the short rotation trees, which is another alternative, take a shorter time for harvesting and get the return faster. Therefore, it is necessary for the promoting of planting economic forest plantation to inform the fact on the time of getting benefit, which is a challenge of the RFD in convincing farmers to participate in the project. However, the project of RFD can be considered as one of the methods that increases the economic forest plantation area only. The management should take the growing timber demand into account by combining with sustainable management of natural forests and development of efficient production from forest plantations.

\section{ACKNOWLEDGEMENT}

I would like to express my sincere thanks to Asia Pacific Network for Sustainable Forest Management and Rehabilitation (APFNet) and the Royal Forest Department (RFD) for support my study at Beijing Forestry University during 2016-2018. In addition, I am very grateful to Prof. Dr. Liu Junchang, my supervisor for instruction and advice and thanks Mr. Supparat Samran and Mr. Surat Kanjanakunchorn for additional suggestions.

\section{REFERENCES}

1. NESDB: Office of the National Economic and Social Development Board. 2016.The Eleventh National Economic and Social Development Plans (Plan $11^{\text {th }}$ 2012-2016), Chapter 8: Strategy for Managing Natural Resources and the Environment to Achieve Sustainability. Bangkok, Thailand.

2. NESDB: Office of the National Economic and Social Development Board. 2017.The Twelfth National Economic and Social Development Plans (Plan 12 ${ }^{\text {th }} 2017-2021$ ), Development Strategy 4: Strategy for EnvironmentallyFriendly Growth for Sustainable Development Bangkok, Thailand.

3. RFD.2017a. Forestry Statistics Data 2017. Bangkok: RFD. (In Thai)

4. RFD.2009. Forestry in Thailand: The 113 years of Royal Forest Department. Bangkok, Thailand.

5. RFD.2007. Forestry Statistics Data 2007. Bangkok: RFD. (In Thai)

6. APFNet. 2016. Degraded Forest Rehabilitation and sustainable Forest management in the Asia-Pacific Region: Development of an Integrated Forest Management in Thailand, China Forestry Publishing House. Beijing. China. 
7. Jongklai. 2017. The policy to increase forest area. Available at $:<\mathrm{ht} \mathrm{tp}: / /$ fores t in fo.forest.go.th Thai) /pfd/Download/DL115.pdf $>$. (accessed 13-10-2017) (In

8. RFD. 2017b. The Strategic Royal Forest Department in period 20 years2017 - 2036.Strategic Issue 3: Promote Forest Business and Economic Forests from forest planting and community promotion, urban / rural communities are green areas. Bangkok: RFD. (In Thai)

9. Niwat.2017. Progress on Forest Plantation Act B.E. 2535 (1992), and subsequent amendments B.E.2558 (2015) A $\quad$ v a $\quad$ i 1 a $\quad$ b 1 e $\quad$ a $:<$ http://forestinfo.forest.go.th/pfd/Download/DL118.pdf $>$. (accessed 13-10-2017)(In Thai)

10. Thada. 2017 . e-tree system. Available at $:<$ http://forestinfo.forest.go.th/pfd/Download/DL122.pdf $>$. (accessed 13-10-2017) (In Thai)

11. Seri. 2017. Promotion of economic tree planting. PowerPoint present at the meeting to practice the fiscal year 2017 (January 30, 2017). (In Thai)

12. RFD, Forest Certification Office. 2017. RFD Single W i n d o w S y s t e m. A v a i l a b l e at: $<$ https://nsw.forest.go.th/rfdportal/Home.aspx, 016.> (accessed 12-10-2017) (In Thai)

13. Nikom. 2017. Trends in the economic forest of

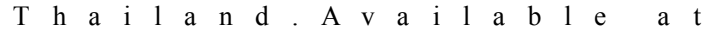
$:<$ http://forestinfo.forest.go.th/pfd/Download/DL116.pdf $>$. (accessed 13-10-2017)(In Thai)

14. RFD, Planning and Budgeting Division, 2016. Action Plan RFD 2016. Bangkok: RFD. (In Thai)

15. RFD, Planning and Budgeting Division, 2017. Action Plan RFD 2017. Bangkok: RFD (In Thai)

16. Vichan. 2016. Thailand National Single Window: NSW. Available at $:<$ http://library2.parliament.go.th/ebook/contentissue/2559/hi2559-035.pdf>, page 13,15. (accessed 12-102017) (In Thai)

17. FAO (2010). Enhancing stakeholder participation in national forest programmes. A training manual. Available at: $<$ http://www.fao.org/docrep/014/i1858e/i1858e00.pdf $>$. (accessed 12-10-2017)

18. OPDC. 2015.Office of Public Sector Development Commission. Licensing Facilitation Act, B.E. 2558 (2015). Bangkok. 